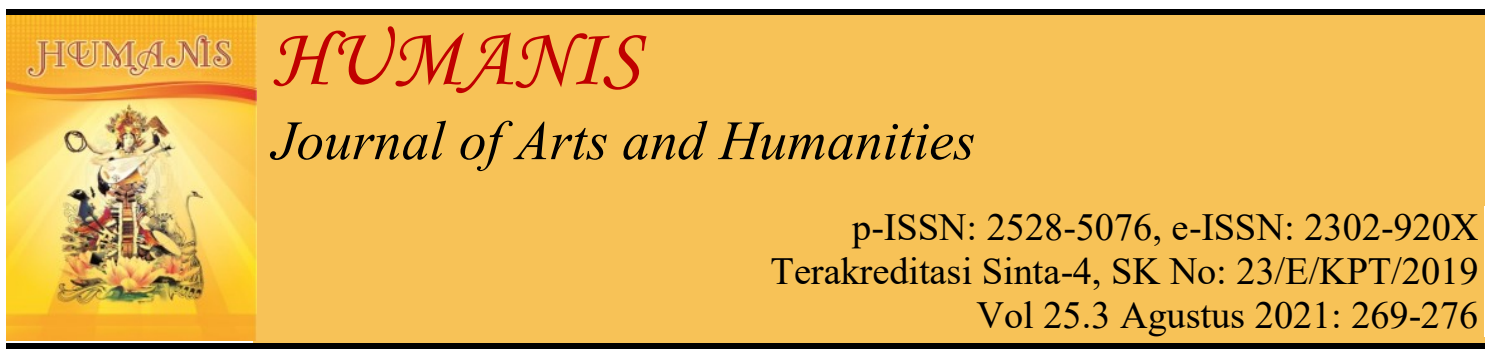

\title{
Women's Language Features in Emily in Paris: A Sociolinguistics Study
}

\author{
Meyliana Eka Putri, Ni Luh Sutjiati Beratha, Sang Ayu Isnu Maharani \\ Udayana University, Denpasar, Bali, Indonesia \\ Correspondence email: meylianaekaptr@gmail.com, sutjiati59@gmail.com, \\ isnu maharani@unud.ac.id
}

\begin{tabular}{|c|c|}
\hline Article Info & Abstract \\
\hline Submitted: $19^{\text {th }}$ April 2021 & This undergraduate thesis discusses the usage of women's \\
\hline Revised: $10^{\text {th }}$ May 2021 & language features in the television series Emily in Paris. \\
\hline Accepted: $16^{\text {th }}$ May 2021 & $\begin{array}{l}\text { The study analyzes the features of women's language and } \\
\text { its functions in the television series. This study uses }\end{array}$ \\
\hline Keywords: Women's language & observation method in collecting the data. The data were \\
\hline features, feminism, Emily in Paris & $\begin{array}{l}\text { taken from Emily in Paris television series and the movie } \\
\text { scripts. Descriptive qualitative method is used to analyze } \\
\text { the data by applying women's language features theory by }\end{array}$ \\
\hline Corresponding Author: & Lakoff. Based on the analysis and data taken, there are \\
\hline $\begin{array}{l}\text { MeylianaEkaPutri, } \\
\text { meylianaekaptr@gmail.com }\end{array}$ & $\begin{array}{l}480 \text { utterance of women's language features found and ten } \\
\text { features of women's language used by the female }\end{array}$ \\
\hline $\begin{array}{l}\text { DOI: } \\
\text { https://doi.org/10.24843/JH.2021.v2 } \\
\text { 5.i03.p02 }\end{array}$ & $\begin{array}{l}\text { the most used feature and precise color terms is the least } \\
\text { used feature. }\end{array}$ \\
\hline
\end{tabular}

\section{INTRODUCTION}

Men and women are known to speak differently. In the old days, men were perceived as the heart of society while women were seen as an outsider and were invisible in the eye of society (Coates, 2016: 5). Gender stereotype is one of the most powerful influences in shaping society's behavior where it has the power to dictate how women and men should behave (Aries, 1996: 187). People grow up with the idea that women are more talkative than men, that women are more expert in mannerisms, and so on (Coates, 2016: 86). These stereotypes on women's and men's use of language are still believed by the society up to this day.

Women's language is described as language that is used restricted to women and descriptive to women alone (Lakoff,
1973: 48). The language that women use interpreted by Eckert and McConnellGinet (2003: 159) are classified as "powerless" which makes women seem disempowered and they are simply saying what the addressee expects them to say. Lakoff proposed ten women's language features which are: lexical hedges, tag questions, rising intonation on declaratives, 'empty' adjectives, precise color terms, intensifiers, 'hypercorrect' grammar, 'superpolite' forms, avoidance of strong swear words, and emphatic stress.

As the position of women in society is judged by the language they use, this study is aimed to identify the usage of women's language features and the functions by analyzing a television series entitled Emily in Paris. 


\section{METHOD AND THEORY}

\section{Data Source}

The primary data source of this study was taken from 10 episodes of the television series Emily in Paris with 22 minutes of time allocation in each episode which are streamed on Netflix website as well as its script.

There are several reasons on why the data source is chosen. First, television series is a reflection of reality. Second, Emily in Paris uses simple everyday English. Third, there are plenty of female characters in the television series. Fourth, the television series aired recently in the end of 2020. Therefore, the television series is not outdated which is suitable to be the data source of this study.

\section{Data Collection}

The study applied observation method with note-taking technique and recording technique in collecting data. Data such as intensifiers, lexical hedges or fillers, and 'empty' adjectives were collected using AntConc tool to generate the data. Meanwhile, the data such as rising intonation on declaratives, precise color terms, emphatic stress, hypercorrect grammar, avoidance of strong swear words, tag questions, and superpolite forms were collected by watching each episode while highlighting the movie scripts and taking notes.

\section{Data Analysis}

A descriptive qualitative analysis was applied in analyzing this study. According to Yin (2011: 6), qualitative research enables researchers to conduct and in-depth study on various fields of topics. The data collected were analyzed based on women's language features theory by Lakoff (1975). The analysis of the data used description to explain the features and functions of women's language found in the data source.

\section{Data Presentation}

The data analyzed that was chosen randomly was presented using informal method consisting of multiple paragraphs using descriptive method to present the interpretations of the observations of the data taken.

\section{Literature Review}

Hedenmalm (2012) discusses about the femininity and masculinity of female and male characters in Disney movies based on the language they use. This thesis uses Lakoff's (1975) women's language features as the constructing theory. The study shows that the theory proposed by Lakoff (1975) is not used consistently as some of women's language features are used by men. Unfortunately, this thesis uses several data sources which fails to bring the focus of the study and makes it difficult to comprehend.

Rubbyanti (2017) discusses about the usage of women's language features in a classical miniseries Sense and Sensibility. Women's language features theory by Lakoff (1975) is used in this study. This article shows that nine out of ten features of women's language features are used in the miniseries. However, the data source in this study was set in the $18^{\text {th }}$ century therefore is not relatable in present era.

\section{Women's Language Features}

Women's language is described as language that is used restricted to women and descriptive to women alone (Lakoff, 1973: 48). There are ten features of women's language. The explanations are as follows:

\section{Lexical Hedges or Fillers}

Words such as I think, I'm sure, sort of, etc. are classified as lexical hedges which are used to decrease the strength of an assertion. Women use hedges because they are not allowed to assert strong 
opinions. Lakoff (1975: 53) identified that women use fillers to express lack of confidence.

\section{Tag Questions}

A question tag is a form of yes-no question that is not too assertive but confident enough to be stated. A tag question is a mediator between a statement and a yes or no question, which indicates more confidence than a yes or no question but is not as confident as a statement (Lakoff, 1975: 15).

\section{Rising Intonation on Declaratives}

Lakoff (1975: 53) states that women are inclined to use a form of declarative answer rather than a question. Rising intonation on declaratives is a type of yes or no question to express a hesitance from the speaker (Lakoff, 1975: 17). It indicates the speaker's hesitance to answer as well as a form of seeking confirmation from the addressee. The usage of rising intonation on declaratives also makes women's speech sounds more 'polite' than men's as it does not impose the speaker's view to the addressee, the speech remains open to discussion.

\section{4. 'Empty' Adjectives}

Women often use adjectives such as divine and pretty which are considered as 'empty' adjectives (Jespersen, 1922: 250). Furthermore, Jespersen explains that women are fond of hyperbole which regard to the intensity of the use of the adjectives which often used with are in contrast to their 'true' meaning. For instance, women would say "What a divine idea!" when they actually mean otherwise to respect the person they are talking to.

\section{Precise Color Terms}

Words such as magenta, violet, lavender, burgundy, and so on are often used by women. These are words that describe detailed description of colors. Women tend to use these terms than men as women have larger stock of words since colors are related to their specific interests (Lakoff, 1975: 53). These interests are activities such as sewing, fashion, decorating and so on.

\section{Intensifiers}

The word such as 'so' and 'just' are classified as intensifiers and are often applied by women to exert a strong feeling about something without showing how strong the feeling is (Lakoff, 1975: $55)$.

\section{7. 'Hypercorrect' Grammar}

Women are inclined to use the standard form of language which is classified as 'hypercorrect'. As Holmes (2013: 303) observed that women consistently use standard form of verbs. The usage of 'hypercorrect' grammar is in relation to politeness, women are perceived to use standard form of language consistently which shows politeness. Women are expected to act properly, politely, and talk in a mannerly way. Women are not expected to speak in roughly manner (Lakoff, 1975: 55). For instance, boys usually say goin, singin, ain't and so on. While women stick to the standard form of language such as going, and singing (Lakoff, 1975: 55).

\section{Superpolite Forms}

Women are seen to be the keeper of morale and civility and people tend to speak in an especially "polite" way to women (Lakoff, 1975: 51). Related to women's usage of hypercorrectness in grammar, women are expected to talk in more politely manner than men (Lakoff, 1975: 55). As observed by Holmes (1995: 193-197) that in a conversation, women are more orientated to affective and interpersonal meaning. On the other 
hand, men are more oriented to the goals of the conversation (Coates, 2016: 107).

\section{Avoidance of Strong Swear Words}

Bryson (1990: 498) explains that profanity is a part of language to express strong feelings harmlessly. It is believed that men use swear words more than women. The words that are considered as profanities have been discouraged to be used in daily life (DeFrank and Kahlbaugh, 2018: 2). In western culture, expletives are related to power and masculinity, this result to using profanities is regarding to masculinity characteristics not femininity (De Klerk, 1997: 147).

\section{Empathic Stress}

Emphatic stress or boosting devices are words such as brilliant, amazing, etc. As cited from (Holmes, 2013: 304), Lakoff explained that women tend to use those words more in their daily conversation comparing to men to express women's lack of confidence and to express uncertainty. The use of boosting devices is also to express extra reassurance to the addressee so they are more convinced in what the speakers are saying (Holmes, 2013: 304). In addition, according to Lakoff, women use boosting devices to get attention from the addressee and be taken seriously (Holmes, 2013).

\section{RESULT AND DISCUSSION}

The usage of women's language features by the female characters in Emily in Paris as well as the functions of each features are the main discussions in this study.

\section{Women's Language Features in Emily in Paris}

All features of women's language are found in the television series Emily in Paris. Lexical hedges or fillers is the most used feature while precise color terms is the least used feature found in the television series. The explanations are presented below.

\section{Lexical Hedges or Fillers}

[1] Antoine: Hm. And how do things look from that point of view?

Emily: I think you have an amazing, sexy product that could practically induce pregnancy in older women.

Data in the example above explains a conversation between Emily and her client as well as her boss. Antoine then asks Emily on what she thinks about his product. There are two functions on the usage of hedges and fillers which are as weakener or strengthener of an utterance (Brown and Levinson, 1978: 147). Based on the data mentioned above, Emily starts her sentence with the filler "I think" to express an opinion that is not too strong which functions as a weakener of utterance. She respects Antoine therefore Emily tries to make the conversation as polite as possible therefore she uses the filler "I think" to express her feelings about Antoine's product.

\section{Tag Questions}

[2] Emily: It's amazing, isn't it? The entire city looks like Ratatouille. Doug: It's beautiful.

Data in example above explains that in this episode, Emily is on the phone with her boyfriend in Chicago, Doug. They are on a video-call feature and Emily is showing Doug the view of Paris at night. Emily implies that the view that they are seeing is amazing. She asks Doug whether or not the view is amazing. The tag question "isn't it" is used after Emily states that the view is amazing. Tag question is sometimes used when both the speaker and hearer know what the answer to the question must be, where the question does not need confirmation, it is a way to initiate "small talk" (Lakoff, 
1975: 16). The tag question used in this data is not expecting a yes or no answer. Emily uses the question tag for a question that both of them already know the answer to. It is a fact that the view is "amazing", she does not need a confirmation, Emily is just beginning the conversation so she is implying a small talk using the tag question.

\section{Rising Intonation on Declaratives}

[3] Doug: I packed, I took a week off work, and then I thought, "What am I gonna do there all day?"

Emily: What? Uh, I don't know. See the sights? I mean, Paris is kind of famous for its sights.

Example in data above explains the scene where Emily is on the phone with her boyfriend in Chicago, Doug. Doug and Emily have planned to have a vacation for the both of them. Doug is about to visit Emily in Paris. However, Doug doubts his decision to go to Paris and is telling Emily about his doubt on the phone. Emily is confused and angry with Doug's decision as it is strange that he changes his plan so sudden. One of the functions of rising intonation on declaratives is to leave a discussion open (Lakoff, 1975: 18). In this scene, Doug is confused on what he will do when he is in Paris, Emily answers with a statement and rise her intonation on the sentence "see the sights?" to state the obvious that there are a lot of things he can do in Paris and to keep the conversation open for discussion.

\section{Precise Color Terms}

[4] Emily: Won't be a problem, I wore all black.

Sylvie: That's not black. That's offblack.

Example in data above explains where Emily and several of her colleagues are about to meet the famous fashion designer, Pierre Cadault. $\mathrm{He}$ is very sophisticated and a very important client to the firm. Therefore, everyone who is going to meet him needs to behave. Sylvie warns Emily to behave herself and just keep silent when meeting him. Emily says it won't be a problem as she wears black outfit which will not stand out. However, Sylvie comments that the outfit Emily is wearing is not black, but "offblack". "Off-black" is a term for a shade of color that is not as intense as black, lighter than black but darker than gray.

\section{5. 'Empty' Adjectives}

[5] Emily: The chateau is so beautiful! I'd love a tour.

Camille's mother: We don't give tours of the chateau. We live here.

The example in data above explains that in this episode, Camille has an idea on her family business to be marketed by Savoir, Emily's firm. Therefore, Emily is invited to come to Camille's chateau in Champagne to talk about business with Camille's mother. The data taken above is a scene where Emily has just arrived at the chateau for the first time and she expresses her personal opinion on the chateau. Emily uses the adjective "beautiful" to express an emotional reaction towards the chateau as it is a traditional French chateau where she has never been before. Emily also uses the adjective to be taken seriously in a conversation since she is a stranger to Camille's mother and she wants to win her heart by complimenting her chateau.

\section{Intensifiers}

[6] Camille: I don't know. Either he expects me to move across the country and leave my whole life behind or this is his way of breaking up with me.

Emily: I'm so sorry. 
The example in data above explains that in this episode Emily finds Camille and Gabriel arguing in front of her apartment. She then approaches Camille and asks what is going on. Camille explains that Gabriel has decided to move to Normandy, open a restaurant there and leave his job in Paris without talking to Camille first. Emily sympathizes over Camille's situation and says she is "so sorry". Lakoff (1975: 15) stated that the usage of intensifier is to conceal strong feelings in an utterance. However in the data taken above, Emily uses the intensifier "so" before "sorry" to emphasize the true intention of her statement. Emily intensifies her intention to sympathize over Camille's situation to make sure that Camille understands that she is there for her.

\section{Hypercorrect Grammar}

[7] Emily: May I ask who's responsible for your social media here?

Example in data above explains that in this episode, Emily is on a first corporate meeting since she arrived from Chicago. She gathers her colleagues to explain her ideas on how she could change Savoir's marketing to a better one. She gives an idea to use social media more as a marketing strategy. In the data taken above, Emily uses hypercorrect grammar such as "May I ask" to show respect to her colleagues and to be seen as someone who has good manner. She wants to give a good first impression to her French colleague and show that she is intelligent as well as professional.

\section{Superpolite Forms}

[8] Emily: Do you mind if I ask you a couple of questions?

Example in data above explains that in this episode, Emily is invited to see a shooting for De L'Heure perfume commercial in Paris with Sylvie and Antoine. There, she approaches the female model for the shoot to make a video for her Instagram account, emilyinparis. In interacting, people need to be desirable therefore they use politeness forms (Brown and Levinson, 1978: 62). In the data taken above, Emily asks the model if she can ask a couple of questions to the model for her Instagram account. Because Emily has just met the model and they are strangers. Emily uses superpolite forms of language "Do you mind" in the beginning of the sentence to show respect to a stranger and to lure her for answering questions from Emily.

\section{Avoidance of Strong Swear Words}

[9] Emily: Your language is seriously effed up.

The data above gives an example where in this episode Emily learns more about the French language. She learns that French has genders for nouns. However, she is confused as why does "vagina", a female reproductive part, is considered as masculine in French. She then confronts Sylvie and asks for the reason why. Sylvie answers with uncertainty. Emily is even more confused with Sylvie's answer. From the data taken above, Emily uses the term "effed" as form of avoidance of using the swear word "fucked". Emily uses the term "effed" to express her confusion in French language, but she still respects Sylvie as her boss so she doesn't use the swear word "fucked". As speaker status is a crucial part as it indicates speaker power (Johnson and Lewis, 2010: 109).

\section{Empathic Stress}

[10] Emily: It's amazing, isn't it? The entire city looks like Ratatouille.

The example in data above explains the scene where Emily is on the phone with her boyfriend in Chicago, Doug. She is 
showing Doug the view of Paris that she is currently seeing. Emily describes the view as "amazing" and stresses on that word to express her admiration towards it. The usage of empathic stress or boosting device is to draw attention in a conversation (Eckert and McConnellGinet, 2003: 153). Thus, the usage of this boosting device in the example above is to make the addressee, Doug, more convinced and attentive to what Emily is saying. At first, Doug doesn't agree on Emily's decision to go to Paris. Here, in the data taken, Emily is trying to convince Doug that the decision she made is the right decision by saying how "amazing" Paris is.

\section{CONCLUSION}

The study focuses on the usage and functions of women's language features in a television series. Based on the analysis above, there are several points that can be drawn.

The first point of conclusion is that according to the television series, women's language features are used by the female characters in Emily in Paris. The female characters in Emily in Paris are found using all ten features of women's language features. Lexical hedges or fillers is used 242 times, tag questions is used 20 times, rising intonation on declaratives is used 37 times, empty adjectives is used 18 times, precise color terms is used one time, intensifiers is used 82 times, hypercorrect grammar is used 19 times, superpolite forms is used 28 times, avoidance of strong swear words is used 25 times, and empathic stress is used 25 times. Based on the data presented, the most used feature is lexical hedges or fillers and the least used feature is precise color terms.

The second point is that the female characters are not consistent in using the features. Though all of the features are found used by the female characters in
Emily in Paris, they are also found using strong swear words when talking to a close friend and not using standard forms of English to shorten their utterances.

\section{REFERENCES}

Aries, E. (1996). Men and Women in Interaction. New York: Oxford University Press.

Brown, P., \& Levinson, S. C. (1987). Politeness: Some universals in language usage. Cambridge University Press.

Bryson, B. (1990). The Mother Tongue: English, and How it Got That Way. New York: William Morrow.

Cameron, D. (2003). Gender and Language Ideologies. In: Holmes, J. and Meyerhoff, M. (ed.) The Handbook of Language and Gender. Cornwall: Blakewell Publishing.

Coates, J. (2016). Women, men and language: $A$ sociolinguistic account of gender differences in language (Third edition). Routledge.

DeFrank, M. and Kahlbaugh, P. (2018). Language Choice Matters: When Profanity Affects How People are Judged. Journal of Language and Social Psychology. Vol. 38, No.1, 1-16. Retrieved on $1^{\text {st }}$ March 2021 from https://journals. sagepub.com/doi/10.1177/0261927 X 18758143.

De Klerk, V. (1992). How taboo are taboo words for girls? Language in Society, Vol. 21, No. 2, 277-289. Retrieved on $5^{\text {th }}$ March 2021 from https://www.researchgate.net/publi 
cation/29807278_How_Taboo_Are _Ta boo_Words_for_Girls

Eckert, P. and McConnell-Ginet, S. (2003). Language and Gender. New York: Cambridge University Press.

Hedenmalm, L. (2012). Language and Gender in Disney: A Study of Male and Female Language in Walt Disney Movies (undergraduate thesis). Luleå University of Technology.

Holmes, J. (1990). Hedges and boosters in women's and men's speech. Language \& Communication. Vol. 10, No.3, 185-205.

Holmes, J. (2013). An introduction to sociolinguistics (4. ed). Routledge.

Holmes, J., \& Meyerhoff, M. (Eds.). (2003). The handbook of language and gender. Blackwell.

Jespersen, O. (1922). Language: Its Nature, Development, and Origin. London: George Allen \& Unwin.

Johnson, D. I., Lewis, N. (2010). Perceptions of Swearing in the Work Setting: An Expectancy Violations Theory Perspective. Communication Reports. Vol. 23, No. 2, 106-118. Retrieved on $7^{\text {th }}$ March 2021 from https:/www.tandfonline.com/doi/a bs/10.1080/08934215.2010.511401

Lakoff, R. (1973). Language and Woman's Place. Language in Society. Vol. 2, No. 1, 45-80.

Lakoff, R. (1975). Language and Woman's Place. London: Cambridge University Press.
Rubbyanti, M. A. (2017). Women's Language in Sense and Sensibility BBC Miniseries: A Sociolinguistic Study. Sastra Inggris - Quill. Vol. 6, No. 1, 43-55. Yogyakarta State University. Retrieved on $7^{\text {th }}$ November 2020 from http://journal.student.uny.ac.id/ojs/i ndex.php/quill/article/view/6370.

Yin, R. K. (2011). Qualitative Research from Start to Finish. New York: The Guilford Press.

Talbot, M. (2003). Gender Stereotypes: Reproduction and Challenge. In: Holmes, J. and Meyerhoff, M. (ed.) The Handbook of Language and Gender. Cornwall: Blakewell Publishing.

Weatherall, A., Gallois, C. (2003). Gender and Identity: Representation and Social Action. In:Holmes, J. and Meyerhoff, M. (ed.) The Handbook of Language and Gender. Cornwall: Blakewell

Publishing. 